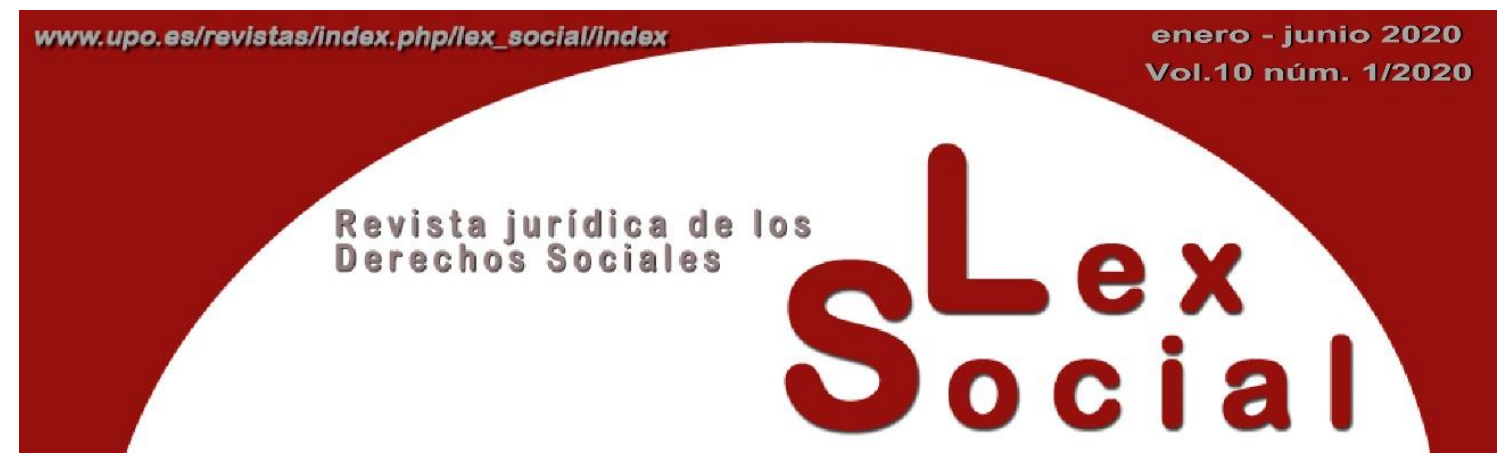

\title{
THE UN COMMITTEE ON ECONOMIC, SOCIAL AND CULTURAL RIGHTS DECISION IN LÓPEZ ALBÁN V. SPAIN: THE NEED FOR A PROPORTIONALITY ASSESSMENT IN EVICTION PROCEDURES
}

\section{LA DÉCISION DU COMITÉ DES DROITS ÉCONOMIQUES, SOCIAUX ET CULTURELS DANS L'AFFAIRE LÓPEZ ALBÁN C. ESPAGNE : LA NÉCESSITÉ D'UN CONTRÔLE DE PROPORTIONNALITÉ DANS LES PROCÉDURES D'EXPULSION LOCATIVE}

JUAN CARLOS BENITO SÁNCHEZ

Researcher at F.R.S.-FNRS (FRESH) Centre de philosophie du droit, UCLouvain (Belgium)

Artículo recibido el 14 de noviembre de 2019

Artículo aceptado el 28 de noviembre de 2019

\section{SUMMARY}

On 30 October 2019, the UN Committee on Economic, Social and Cultural Rights made public its decision in the case of López Albán v. Spain. The case concerned a single mother with six children occupying a vacant apartment owned by a financial entity out of necessity, after being excluded from the possibility of obtaining public housing. The family was eventually evicted without adequate alternative accommodation. The Committee found that this eviction violated the right to adequate housing enshrined in the International Covenant on Economic, Social and Cultural Rights. This article summarises the case, provides a contextual analysis in light of recent developments, makes a comparison with the case law of the European Court of Human Rights, and notes some legal avenues the Committee could explore in future decisions.

KEYWORDS: CESCR, right to housing, evictions, proportionality assessment, Spain. 


\section{RÉSUMÉ}

Le Comité des droits économiques, sociaux et culturels a publié sa décision dans l'affaire López Albán c. Espagne le 30 octobre 2019. Il s'agit d'une affaire où une mère célibataire avec six enfants occupait un appartement vide propriété d'un établissement financier par nécessité, après avoir été exclue de la possibilité d'obtenir un logement public. La famille fût finalement expulsée, sans une alternative de relogement adéquate. Le Comité a trouvé que cette expulsion a constitué une violation du Pacte international relatif aux droits économiques, sociaux et culturels. Cet article présente un sommaire de l'affaire, offre une analyse contextuelle à la lumière de certains développements récents, fait une comparaison avec la jurisprudence de la Cour européenne des droits de l'homme, et remarque quelques avenues juridiques que le Comité pourrait explorer dans ses décisions à venir.

MoTS-CLÉS: Comité DESC, droit au logement, expulsions locatives, contrôle de proportionnalité, Espagne.

TABLE OF CONTENTS

\section{Introduction.}

2. The facts.

\section{The CESCR decision.}

\section{Commentary.}

4.1. A strong protection for tenants against eviction: The obligation for courts to conduct a proportionality assessment.

4.2. The contrasting approach of the European Court of Human Rights.

4.3. What comes next? Two possible future legal avenues for the CESCR to explore.

\section{Conclusion.}

Bibliography.

\section{Introduction.}

On 30 October 2019, the UN Committee on Economic, Social and Cultural Rights (CESCR) made public its decision in the case of López Albán v. Spain. ${ }^{1}$ The case concerned a single mother with six children occupying a vacant apartment owned by a financial entity out of necessity, after being excluded from the possibility of obtaining public housing. The family was eventually evicted without adequate alternative accommodation. In one of the emergency shelters they stayed at, two of the minor children were separated from their mother and siblings.

\footnotetext{
${ }^{1}$ United Nations, Committee on Economic, Social and Cultural Rights, Communication no. 37/2018, López Albán, E/C.12/66/D/37/2018 (11 October 2019). At the time of writing, the decision is only available in Spanish. All translations in this article are the author's and all errors remain my own. I would like to thank Javier Rubio and the Asamblea de Vivienda de Carabanchel for their excellent work on this case.
} 
The CESCR found that Spain had violated the right to housing of the applicant and her children, since their eviction had been carried out without ensuring adequate alternative accommodation and without a prior proportionality assessment. Spain also violated their right to housing insofar as the author was excluded from public housing on the grounds that she had been occupying a dwelling without a legal title.

\section{The facts.}

Maribel Viviana López Albán lived with her six children in an apartment in Madrid. After paying rent regularly for a year, she found out that the alleged landlord was a fraudster and that he did not actually own the apartment, so she stopped making payments to him. Later that year, the financial entity who actually owned the apartment reported her for illegal occupation. Following criminal proceedings, the Madrid Criminal Court found her guilty of a crime of trespassing (usurpación), finding a partial extenuating circumstance since the family income at that time was very low and this did not allow them to subsist. ${ }^{2}$

The Court ruled however that, although the family's situation was one of severe necessity, they were not destitute, nor was it impossible for the author to solve their situation by other lawful means. A complete exonerating circumstance was thus not found in this case. The author appealed this judgment, but the Court of Appeals confirmed the ruling of the lower court. The author subsequently tried to negotiate with the financial entity to sign a rental contract with them, to no avail.

While staying at this apartment, the author had applied for public housing to the authorities of the Madrid Autonomous Community, but her application was rejected on the basis that she was occupying a dwelling without a legal title. This constitutes grounds for exclusion according to the applicable legal norm: applicants must not "be occupying a property or dwelling without sufficient legal title and without the owner's consent."3 Even though she was placed in an emergency housing programme, these units are allocated as a matter of priority, and she was still on the waiting list at the time that a court order was made for her eviction.

After a first eviction attempt halted by housing activists and civil society organisations, a second attempt was carried out, and the family then decided to voluntarily leave the apartment. Social services offered them a stay at a hostel in an industrial area for a few nights, after which the family had to move to a different hostel where they shared bunk beds with another family. The family was then placed in a third hostel in two separate

\footnotetext{
${ }^{2}$ The crime of usurpación takes places when someone occupies a property, dwelling, or building without due authorisation or when they remain there against the will of its owner. See Spain, Ley Orgánica 10/1995, de 23 de noviembre, del Código Penal (BOE núm. 281, de 24 de noviembre de 1995), art. 245.2.

3 See Spain, Autonomous Community of Madrid, Decreto 52/2016, de 31 de mayo, del Consejo de Gobierno, por el que se crea el Parque de Viviendas de Emergencia Social y se regula el proceso de adjudicación de viviendas de la Agencia de Vivienda Social de la Comunidad de Madrid (BOCM núm. 261, de 31 de octubre de 2016), art. 14.1.f.
} 
rooms segregated by sex, with the consequence that the two male seven-year old twins had to sleep on their own, separated from their mother and sisters.

The author brought a complaint before the CESCR claiming that her eviction violated her right to housing and that of her children under Article 11 ICESCR, since it was carried out without securing adequate alternative accommodation for them. She also argued that the relevant authorities did not provide her with public housing because she was occupying an apartment without a legal title at the time, requirement which puts her in an impossible situation and breaches her right to housing.

Since the eviction had already taken place at that time, the CESCR requested Spain to adopt interim measures consisting on immediately providing the family with adequate and stable alternative accommodation, in the framework of a genuine and effective consultation with the author to prevent eventual irreparable risks to her and her children. The author claimed that Spain had not complied with this request and had thus breached the Optional Protocol to the ICESCR, which refers to the CESCR's power to request, at any time after the receipt of a communication and before a determination on the merits has been reached, "that the State Party take such interim measures as may be necessary in exceptional circumstances to avoid possible irreparable damage to the victim or victims of the alleged violations." 4

\section{The CESCR decision.}

The Committee started by recalling the duty of the state to provide adequate alternative accommodation in cases of need and the safeguards afforded by the ICESCR against forced evictions, building on its General Comment No. $4,{ }^{5}$ its General Comment No. $7,{ }^{6}$ and its decision in the case of Ben Djazia and Bellili. ${ }^{7}$ These considerations apply as well to occupations without a legal title, since "this occupation can become, for certain people, a form of housing, so this could come within the scope of protection of the right to housing." 8

Even when evictions are justified, for instance in the case of a persistent nonpayment of rent or in the case of damages to the rented property without a reasonable cause, the procedures conducive to an eviction and the eviction itself must be compatible with the ICESCR and must guarantee that all appropriate legal remedies are available to the persons affected..$^{9}$ Authorities must ensure that forced evictions are carried out according

\footnotetext{
${ }^{4}$ United Nations, General Assembly, Optional Protocol to the International Covenant on Economic, Social and Cultural Rights, A/RES/63/117 (10 December 2008), art. 5.

${ }^{5}$ United Nations, Committee on Economic, Social and Cultural Rights, General Comment no. 4: The right to adequate housing (art. 11 (1) of the Covenant), E/1992/23 (1 January 1992).

${ }^{6}$ United Nations, Committee on Economic, Social and Cultural Rights, General Comment no. 7: The right to adequate housing (art. 11 (1) of the Covenant): Forced evictions, E/1998/22 (20 May 1997).

${ }^{7}$ United Nations, Committee on Economic, Social and Cultural Rights, Communication no. 5/2015, Ben Djazia and Bellili, E/C.12/61/D/5/2015 (21 July 2017).

${ }^{8}$ Committee on Economic, Social and Cultural Rights, López Albán, para. 6.2.

${ }^{9}$ Committee on Economic, Social and Cultural Rights, General Comment no. 7, para. 11. 
to legislation which conforms to ICESCR standards and observing the principles of reasonableness and proportionality between the legitimate aim of evicting and the consequences thereof on the persons affected. ${ }^{10}$

It recalled its decision in the Ben Djazia and Bellili case, where the Committee found that:

In some circumstances, the eviction of people living in rental accommodation may be compatible with the Covenant, as long as the eviction is provided for by law and is carried out as a last resort, and that the persons concerned have had prior access to an effective judicial remedy, in order to ascertain that the measure in question is duly justified, for example, in the case of persistent non-payment of rent or of damage to rented property without just cause. In addition, there must be a real opportunity for genuine prior consultation between the authorities and the persons concerned, there must be no less onerous alternative means or measures available and the persons concerned must not remain in or be exposed to a situation constituting a violation of other Covenant or human rights. ${ }^{11}$

The Committee then emphasised the importance of ensuring the right of family members not to be separated from each other, and the distinction between emergency shelter and housing. In certain circumstances, states can show that, despite making all efforts to the maximum of their available resources, it was impossible to offer alternative permanent housing to an evicted person in need of alternative accommodation. In these cases, it is possible to resort to temporary emergency shelter, which needs not fulfil all requirements of adequate housing. Nonetheless, states must ensure that temporary shelter is compatible with the protection of human dignity, that it fulfils all safety requirements, and that it does not become a permanent solution but rather a temporary step towards stable and adequate housing. ${ }^{12}$

The CESCR acknowledged that states can take measures to protect private property and to avoid the illegal, mala fide occupation of buildings. They can also legitimately establish certain conditions that applicants must fulfil in order to obtain social benefits, including housing. However, these conditions must be reasonable and must be carefully designed to avoid stigmatisation: a person's behaviour cannot in itself become a justification for the state's refusal to provide public or social housing. ${ }^{13}$ Judicial and administrative authorities must not perpetuate systemic discrimination against persons living in poverty who occupy a dwelling without an appropriate legal title, both when they are bona fide occupants and when they occupy out of necessity. Moreover, since growing inequality

\footnotetext{
${ }^{10}$ Committee on Economic, Social and Cultural Rights, López Albán, para. 8.2.

${ }^{11}$ Committee on Economic, Social and Cultural Rights, Ben Djazia and Bellili, para. 15.1; Committee on Economic, Social and Cultural Rights, López Albán, para. 8.3.

${ }^{12}$ López Albán, para. 9.4.

${ }^{13}$ López Albán, para. 10.1. 
and speculation in housing markets are at the root of the lack of sufficient affordable housing, states must address these structural causes by means of an adequate and coordinated approach, to the maximum of their available resources. ${ }^{14}$

The Committee noted that the author was found guilty of trespassing and that this is a legitimate ground that can in principle justify the author's eviction. However, the court ordering the eviction did not carry out a proportionality assessment between the legitimate aim of evicting a person guilty of trespassing and the consequences of this eviction for those involved. Whereas the legitimate interest of the owner in recovering possession of their property must be considered:

It is inevitable to make a distinction between individuals who require their property to use it as housing or to secure a vital income, on the one hand, and financial entities who own property, on the other hand, as in the current case. A finding that an eviction is not a reasonable measure in a particular moment does not necessarily mean that an eviction order cannot be made against the occupants at all. Nonetheless, the principles of reasonability and proportionality may require that this order be suspended or postponed to avoid the possibility that the evicted persons become destitute or that other Covenant rights are violated. An eviction order can also be made dependent on other factors, such as requiring public authorities to intervene and assist occupants in order to mitigate the consequences of an eviction. ${ }^{15}$

The Committee then went on to affirm that:

The state party must develop a normative framework regulating evictions of persons occupying property without a legal title, when this property constitutes their home. This framework must stipulate the criteria that judicial authorities must consider when evaluating whether to make an eviction order under those circumstances: for instance, whether the person occupied the dwelling bona fide or not, the personal circumstances of the occupants and their dependants, and whether they cooperated with the authorities in the search for solutions adapted to them. Nevertheless, a state party will violate the right to adequate housing if it stipulates that a person occupying a dwelling without a legal title must be immediately evicted, regardless of the circumstances under which the eviction order would be executed. ${ }^{16}$

The Committee thus found a violation of the author's (and her children's) right to housing on this count.

\footnotetext{
${ }^{14}$ López Albán, para. 10.2.

${ }^{15}$ López Albán, para. 11.5.

${ }^{16}$ López Albán, para. 11.7. 
The Committee subsequently noted that the author had tried to remedy her situation by applying for public housing, but her application was rejected due to the requirement that applicants do not occupy a dwelling without an appropriate legal title or without the owner's consent. For the Committee, this requirement put the author in an impossible situation, forcing her to either live with her children in temporary shared accommodation or to live in destitution before she could apply for public housing. This entailed a second violation of the author's (and her children's) right to adequate housing, since that requirement perpetuated her irregular situation and led her to an eviction, without regard to her situation of necessity. ${ }^{17}$

Finally, the Committee found a third violation, this time of the Optional Protocol to the ICESCR, due to the fact that Spain had not complied with the interim measures requested by the Committee during its examination of the case. Although the state had provided the author with temporary emergency shelter, this did not constitute adequate alternative accommodation. ${ }^{18}$

In light of these violations, the Committee made a series of individual and general recommendations. With regard to the author and her children, Spain must provide them with an effective reparation, which includes a series of elements. If they do not yet have adequate housing, their needs and their priority in the waiting list must be reevaluated with the aim to provide them with public housing or to take other measures to secure adequate housing for them. Spain must also compensate them economically for the human right violations they suffered, and carry with all legal costs for the procedure before the CESCR.

Regarding the general recommendations, Spain must develop a normative framework regulating evictions which allows judicial authorities to carry out a proportionality assessment having regard to the aim pursued by the eviction measure and its consequences on the evicted persons, as well as the compatibility of that measure with the ICESCR. This should apply to all eviction cases, including those of occupation without a legal title. Spain should also ensure that appropriate and effective remedies are available in this context. Access to public or social housing must not be made conditional on any unreasonable requirements excluding persons at risk of destitution, including the requirement in question that applicants not occupy a dwelling without a legal title.

In addition, Spain must adopt the necessary measures to ensure that evictions affecting persons without sufficient resources to find alternative housing for themselves are only carried out after a genuine and effective consultation with them. The state must take all necessary steps to the maximum of its available resources to provide evicted persons with alternative housing, in particular where families, elderly people, children, or other persons in a vulnerable situation are involved. Finally, Spain must elaborate and implement a

${ }^{17}$ López Albán, para. 12.1-12.2.

${ }^{18}$ López Albán, para. 13.1-13.3. 
comprehensive and integral plan to guarantee the right to housing of low-income persons, and must establish a protocol to ensure that the interim measures requested by the CESCR in the framework of the individual complaints mechanism are effectively implemented.

\section{Commentary.}

\subsection{A strong protection for tenants against eviction: The obligation for courts to conduct a proportionality assessment.}

The CESCR decision in López Albán follows the doctrinal line established in the Ben Djazia and Bellili case and in previous CESCR General Comments. It confirms that the protection afforded by the ICESCR against forced evictions also applies to persons occupying dwellings without a legal title, be they bona fide or out-of-necessity occupants. While the private property interests of owners (in particular their right to recover possession) must be taken into account during an eviction procedure, courts must also carefully assess the specific situation of the persons affected before making an eviction order. The granularity in which the Committee spells out the factors that courts ought to take into account in this context is particularly noteworthy. As mentioned above, this includes the presence or not of bona fide, the personal circumstances of the occupants and their dependants, and their cooperation with the authorities in the search for adapted solutions.

Crucially, the state must develop a normative framework regulating evictions that takes account of these factors and allows courts to make proportionality assessments on this basis in all evictions cases - not just those of occupation without a legal title. It is now clear that the immediate eviction of a person occupying a dwelling, with or without a legal title, regardless of their circumstances breaches the ICESCR. This finding casts serious doubts about the compatibility with international human rights law of the existing Spanish legal framework, where a 2018 Act allowing for the immediate eviction of squatters through a summary procedure with no safeguards for the persons involved was recently declared constitutional by the Constitutional Court. ${ }^{19}$ In light of the CESCR decision in López Albán, Spain ought to repeal or amend this particular Act, as well as a sizeable part of the domestic framework governing evictions as a whole.

Furthermore, the decision in López Albán clarifies that the domestic judicial ruling need not be a binary one of evicting or not evicting, but rather courts should consider the possibility of suspending or postponing the eviction or of making it conditional on the effective intervention of social services. A postponement, along with the intervention of social services or help with negotiations with the landlord, could contribute to a solution in some cases. Of course, this requires a strong and active role for social services, notably

\footnotetext{
${ }^{19}$ Spain, Ley 5/2018, de 11 de junio, de modificación de la Ley 1/2000, de 7 de enero, de Enjuiciamiento Civil, en relación a la ocupación ilegal de viviendas (BOE núm. 142, de 12 de junio de 2018); Spain, Tribunal Constitucional (Pleno), Sentencia 32/2019, de 28 de febrero de 2019 (BOE núm. 73, de 26 de marzo de 2019). See further Juan Carlos Benito Sánchez, "Los pronunciamientos del Comité DESC sobre derecho a la vivienda relativos a España. Respuestas jurisprudenciales y legislativas," Lex Social, Revista de Derechos Sociales 9, no. 2 (2019): 579-603.
} 
by improving their ability to act and, importantly, by enlarging the stock of public housing units available as alternative accommodation for individuals and families at risk of eviction.

The Committee also makes a distinction between small and large owners, distinguishing the situation where an individual depends on the rental income of a second property to subsist, on the one hand, from the situation of rentier landlords, investors, and financial entities, on the other hand. The question whether this distinction is relevant or useful in this context is an important one. Although this is clearly an element that should bear some weight, it should not be used to downgrade the protection afforded to tenants renting from small owners, as this comprises the majority of cases in most countries including Spain. ${ }^{20}$ In line with the previous remark, it seems that this factor could be more relevant at the stage of determining whether - and if so, for how long - the eviction could be suspended or postponed, rather than at the stage of determining whether to make an eviction order as a matter of principle, where the circumstances of the individuals and families affected should prevail.

Another significant point is the distinction made by the CESCR between emergency shelter and adequate housing. Emergency shelter must be temporary, must respect the dignity and safety of its occupants, and must constitute a temporary step towards stable and adequate housing. This undermines the argument often made by states that relocating evicted families into hostels exhausts their obligations as to the provision of adequate alternative accommodation. This case showed how this is problematic in many ways. The family went to three hostels: a first one for a few days, a second one were they had to share a room with another family and where one of the children was attacked, and a third one where the seven-year old male twins were separated from their mother and sisters. It is now clear that the obligation to provide adequate alternative accommodation is not discharged simply by making such provisional arrangements. Moreover, even provisional arrangements must fully respect ICESCR standards of dignity and safety.

The Committee treads carefully when qualifying the author's situation. While some might frame it as a case of "illegal occupation" or of squatting, this case is ultimately about a single mother with six children who was initially deceived into renting an apartment from a person who was not the real owner, who then stayed in the apartment out of necessity and who diligently (albeit unsuccessfully) applied for public housing in the meantime. The draconian condition established by the Madrid regional authorities to the effect of rejecting all applicants who were occupying without a legal title put her in an unconscionable situation, where her choices were either squatting or homelessness. It is now also clear that such a requirement is not compliant with international human rights law.

\footnotetext{
${ }^{20}$ It is estimated that $95 \%$ of landlords in the private rental sector in Spain are small owners. See Spain, $\mathrm{La}$ vivienda protegida y el alquiler social en España (Madrid: Defensor del Pueblo, 2019), 16, https://www.defensordelpueblo.es/wp-content/uploads/2019/07/Separata_vivienda_protegida.pdf. 
Finally, the violation of the Optional Protocol as a consequence of the non-compliance with the interim measures requested by the Committee comes in the midst of a legal debate in Spain regarding the binding character of decisions taken by human rights treatymonitoring bodies and whether interim measures requested by these bodies are compulsory or not under the domestic legal order. ${ }^{21}$ Spain has not complied with interim measures in other cases pending before the CESCR. Since there is now an explicit recommendation for Spain to create a protocol ensuring this compliance, it remains to be seen whether the state will change its stance on this question and will begin to systematically implement all interim measures requested by the CESCR. A currently pending case before the Committee involving Belgium, where an interim measure was similarly not implemented, is likely to shine more light in this regard. ${ }^{22}$

\subsection{The contrasting approach of the European Court of Human Rights.}

The CESCR interpretation of Article 11 ICESCR set out above stands in stark contrast with the far more restrictive position taken by the European Court of Human Rights (ECtHR) with regard to Article 8 of the European Convention of Human Rights (ECHR), which protects the right to private and family life and the right to home. Although the material scope of these two articles is certainly very different, it is important to raise attention as to how these divergent interpretations may pose problems for Council of Europe states. $^{23}$

Notably, the ECtHR has recently ruled that, in the private rental sector, states can legislate to preemptively determine the balance between the right to property of owners and the right to housing of occupants, without their being required to allow courts to conduct a proportionality assessment in particular cases before making an eviction order. The ECtHR case law in this regard can be briefly summarised as follows. ${ }^{24}$

\footnotetext{
${ }^{21}$ See Alberto Macho Carro, "La naturaleza jurídica del Comité de derechos económicos, sociales y culturales de Naciones Unidas y de sus pronunciamientos. Especial atención al caso español,” Papeles El tiempo de los derechos (HURIAGE - Red Tiempo de los derechos, 2019), https://redtiempodelosderechos.files.wordpress.com/2019/01/desc-12-19.pdf.

${ }^{22}$ See Tom Denis, "La Ligue des droits de l'Homme s'indigne contre l'expulsion d'un locataire à Etterbeek," RTBF, October 19, 2018, https://www.rtbf.be/info/regions/detail la-ligue-des-droits-de-lhomme-s-indigne-contre-l-expulsion-d-un-locataire-a-etterbeek?id=10051153.

${ }^{23}$ See further Jessie Hohmann, The Right to Housing: Law, Concepts, Possibilities (Oxford: Hart Publishing, 2013). For an overview of the protection against evictions in human rights law, including at the ECHR level, see Padraic Kenna, "Introduction," in Loss of Homes and Evictions across Europe: A Comparative Legal and Policy Examination, ed. Padraic Kenna et al., Elgar Land and Housing Law and Policy (Cheltenham: Edward Elgar, 2018), 1-65.

${ }^{24}$ I have selected the most relevant cases for this section. For a more complete picture, see European Court of Human Rights, Guide on Article 8 of the European Convention on Human Rights: Right to respect for private and family life, home and correspondence,

https://www.echr.coe.int/Documents/Guide_Art_8_ENG.pdf, p. 78-80. See also Sarah Fick and Michel Vols, "Best Protection Against Eviction? A Comparative Analysis of Protection Against Evictions in the European Convention on Human Rights and the South African Constitution," European Journal of Comparative Law and Governance 3 (2016): 40-69; Nicolas Bernard, "La protection conventionnelle du domicile tombe-t-elle lorsqu' on l'invoque contre un particulier? La longue quête de l'horizontalisation des droits de l'homme (obs. sous Cour eur. dr. h., décision F.J.M. c. Royaume-Uni, 6 novembre 2018)," Revue trimestrielle des droits de l'homme 2019, no. 120 (2019): 891-923.
} 
In the 2004 case of Connors, ${ }^{25}$ the Court initially ruled that a notice of eviction issued by a local authority in the case of Travellers halting at a public residential site must be necessary and comply with all procedural guarantees as part of a fair decision-making process before an independent court. This concerned, however, a site owned and managed by a public local authority. ${ }^{26}$

Later on, in the 2008 case of $M c C a n n,{ }^{27}$ concerning the eviction of a woman victim of gender-based violence residing in public housing, the Court resoundingly stated that "the loss of one's home is a most extreme form of interference with the right to respect for the home. Any person at risk of an interference of this magnitude should in principle be able to have the proportionality of the measure determined by an independent tribunal in the light of the relevant principles under Article 8 of the Convention, notwithstanding that, under domestic law, his right of occupation has come to an end." 28 At the same time, the Court conceded that this principle would only apply in exceptional cases, and rejected the argument that a proportionality assessment would have serious consequences for the functioning of the system: "in the great majority of cases, an order for possession could continue to be made in summary proceedings." ${ }^{29}$ It is important to highlight that the landlord in this case was again a public local authority.

In the 2012 case of Yordanova, ${ }^{30}$ the Court then considered that several Roma families which had been living for decades on publicly owned land without a legal title and were threatened with eviction had the right to have the proportionality of this measure examined by an independent court before the eviction was carried out. The state had de facto tolerated the settlement over a long period of time, and the residents had at that point developed strong and long-standing links with one another. For the Court, this situation was to be treated "as being entirely different from routine cases of removal of an

\footnotetext{
25 European Court of Human Rights, First Section, Connors v. the United Kingdom, Application no. 66746/01 (27 May 2004).

26 The term "Travellers" refers to a broad segment of the population characterised by a cultural connection to a nomadic or a semi-nomadic lifestyle. They usually live in mobile homes rather than "bricks and mortar" housing, and they require residential or transit sites with appropriate amenities to be made available in order to secure their right to adequate housing. The Traveller population is numerically significant in countries like Belgium, France, the United Kingdom, or Ireland, but not that much in countries like Spain. See further Elena Marushiakova and Vesselin Popov, "Who Are Roma?," in Roma Culture: Myths and Realities, ed. Elena Marushiakova and Vesselin Popov, Roma Series, Vol. 3 (Munich: Lincom Academic Publisher, 2016); Céline Romainville and Nicolas Bernard, "Le droit à l'habitat des gens du voyage," in Le droit et la diversité culturelle, ed. Julie Ringelheim, Collection du Centre des droits de l'homme de l'Université catholique de Louvain (Brussels: Bruylant, 2011), 745-818.

${ }^{27}$ European Court of Human Rights, Fourth Section, McCann v. the United Kingdom, Application no. 19009/04 (13 May 2008).

${ }^{28}$ European Court of Human Rights, McCann v. the United Kingdom, para. 50.

${ }^{29}$ European Court of Human Rights, McCann v. the United Kingdom, para. 54.

${ }^{30}$ European Court of Human Rights, Fourth Section, Yordanova and Others v. Bulgaria, Application no. 25446/06 (24 April 2012). 
individual from unlawfully occupied property." 31 In this case, the land once again belonged to a public authority. ${ }^{32}$

In the 2013 case of Winterstein, ${ }^{33}$ concerning Travellers in a similar situation to the applicants in Yordanova, the Court followed the same reasoning, even though the land in this case was private-some residents were owners, while other were tenants. The court highlighted that the state had de facto tolerated over decades this long-standing community, whose members had developed strong ties with one another, and found that an eviction according to legislation which did not allow for a prior proportionality assessment by a court would breach Art. 8 ECHR. ${ }^{34}$

It is thus clear that, under the ECtHR's interpretation of Article 8 ECHR, an eviction procedure which does not foresee the possibility to have the proportionality of the eviction examined by an independent court breaches this article where: (a) public or social housing is concerned; or (b) where the state has de facto tolerated residents over a long period of time and these residents have formed strong, long-standing bonds with one another, regardless of whether the land they are occupying is public or private.

The situation drastically changes, however, with regard to the private rented sector. In the 2016 case of Vrzic $^{35}{ }^{35}$ the Court ruled that where the landlord is a private individual or body the aforementioned principle does not apply automatically. In previous cases, "the applicants were living in State-owned or socially-owned flats and an important aspect of finding a violation was the fact that there was no other private interest at stake." 36

This trend was confirmed in the 2018 case of F.J.M., ${ }^{37}$ where the Court confirmed that the UK could legitimately adopt legislation determining the balance between the rights of private landlords and the rights of tenants, so that a procedure for eviction which does not foresee the possibility for courts to carry out a proportionality assessment before making an eviction order does not breach Article 8 ECHR. Since, in this case, the tenant had agreed to the terms of the contract, requiring courts to conduct a proportionality

\footnotetext{
${ }^{31}$ European Court of Human Rights, Yordanova and Others v. Bulgaria, para. 121.

${ }^{32}$ Another important factor for the ECtHR in this case was the Roma ethnicity of the applicants. For the Court, "the applicants' situation as an outcast community and one of the socially disadvantaged groups" must be acknowledged, as "such social groups, regardless of the ethnic origin of their members, may need assistance in order to be able effectively to enjoy the same rights as the majority population." (European Court of Human Rights, Yordanova and Others v. Bulgaria, para. 129).

${ }^{33}$ European Court of Human Rights, Fifth Section, Winterstein and Others v. France, Application no. 27013/07 (17 October 2013).

${ }^{34}$ See also European Court of Human Rights, Third Section, Bagdonavicius and Others v. Russia, Application no. 19841/06 (11 October 2016).

${ }^{35}$ European Court of Human Rights, Second Section, Vrzić v. Croatia, Application no. 43777/13 (12 July 2016).

${ }^{36}$ European Court of Human Rights, Vrzić v. Croatia, para. 66.

${ }^{37}$ European Court of Human Rights, First Section, F.J.M. v. the United Kingdom, Application no. 76202/16 (6 November 2018). 
assessment before making an eviction order would lead to a "wholly unpredictable and potentially very damaging" impact on the private rented sector. ${ }^{38}$

This means that, under the ECtHR's interpretation of Article 8 ECHR, an eviction procedure which does not foresee the possibility to have the proportionality of the eviction examined by an independent court does not breach this article when private rental housing is concerned, unless the state has de facto tolerated residents over a long period of time and these residents have formed strong, long-standing bonds with one another. ${ }^{39}$

By contrast to this, the CESCR's position in López Albán and in Ben Djazia and Bellili confirms that, under international human rights law, courts ought to be able to consider the proportionality of evictions in the private rented sector, even in cases of occupation without a legal title. ${ }^{40}$ Moreover, the state should incorporate this into its domestic legislation, specifying the factors that courts ought to take into account when considering the proportionality of the eviction, such as personal circumstances, the existence or not of bona fide, and the extent of their cooperation with the authorities.

This fragmentation and lack of consistency are likely to weaken legal claims put before courts by persons at risk of being evicted. This may ultimately allow states to disregard the full extent of their human rights obligations by shielding themselves behind concepts like bindingness, enforceability, and hierarchy between different human rights instruments. This can be currently seen in Spain, where the response to the Ben Djazia and Bellili case has been lukewarm and where requests for interim measures made by the CESCR are not always complied with by domestic courts. ${ }^{41}$ At the same time, the expansive interpretation developed by the CESCR is likely to open up new possibilities in the realm of social and political contestation, pushing for legislative change that brings the protection afforded to the right to housing in Spain within these parameters. ${ }^{42}$

\footnotetext{
${ }^{38}$ European Court of Human Rights, F.J.M. v. the United Kingdom, para. 43.

${ }^{39}$ Some doubts remain as to whether the key factor here is the ownership of the dwelling in question (public, social, or private) or the fact that the applicant entered into a contractual relationship with the owner. In Vrzić, the Court noted that "the applicants had not signed any form of agreement whereby they risked losing their home" (European Court of Human Rights, Vrzić v. Croatia, para. 66). In F.J.M., it found that "what sets claims for possession by private sector owners against residential occupiers apart is that the two private individuals or entities have entered voluntarily into a contractual relationship in respect of which the legislature has prescribed how their respective Convention rights are to be respected" (European Court of Human Rights, F.J.M. v. the United Kingdom, para. 42). More clarity from the Court in this sense would be welcome in future judgments; however, the outcome does not seem to differ much in substance

${ }^{40}$ Even though the ECtHR required a proportionality assessment in a case of occupation without legal title, it later clarified that this finding was made in the specific context of the former Yugoslavia, where a publicly owned hotel group paid obligatory monthly contributions into a housing fund and was later privatised. See European Court of Human Rights, F.J.M. v. the United Kingdom, para. 38; European Court of Human Rights, First Section, Brežec v. Croatia, Application no. 7177/10 (18 July 2013).

${ }^{41}$ See further Benito Sánchez, "Los pronunciamientos del Comité DESC sobre derecho a la vivienda relativos a España."

${ }^{42}$ These guarantees against forced eviction become crucial in today's phase of late capitalism, where public and social housing systems across the world are being eroded in favour of the private rented sector and of a homeownership model combined with a value extraction, buy-to-let logic. See David Madden and Peter Marcuse, In Defense of Housing: The Politics of Crisis (London: Verso, 2016); Josh Ryan-Collins et al., Rethinking the Economics of Land and Housing (London: Zed, 2017).
} 


\title{
4.3. What comes next? Two possible future legal avenues for the CESCR to explore.
}

Before concluding this article, I would like to briefly set out some ideas as to what to expect next, and to highlight two legal avenues which could benefit from further development by the CESCR. Since the vast majority of pending cases before the Committee concern the right to housing in Spain, my suggestions here focus on the Spanish context, although many of them can be easily extrapolated to other national contexts.

Firstly, according to the CESCR website, there are currently more than a hundred pending cases against Spain concerning the right to housing. ${ }^{43}$ This reveals a structural problem which should be addressed in a structural manner. Whereas the individual complaints mechanism is highly effective in dealing with more or less isolated human rights violations, it is not well suited to this type of structural, widespread violations. The CESCR could emphasise this structural dimension by conducting a "pilot" procedure, inspiring itself from other international and regional instances such as the ECtHR. In this manner, and taking into account the difference in nature between institutions:

\begin{abstract}
Besides finding an individual violation . . . a "full" pilot judgment consists of the following steps: first, identifying a systematic malfunctioning of domestic legislation or administrative practice; second, concluding that this systematic problem may give rise to numerous subsequent well- founded applications; third, recognizing that general measures are called for and suggesting the form such general measures may take in order to remedy the systematic defect; and fourth, adjourning all other pending individual applications deriving from the same systematic defect. ${ }^{44}$
\end{abstract}

It is true that the individual complaint procedure already allows for the Committee to make recommendations with a general scope, and that the Committee has not shied away from doing so, often in very straightforward terms. However, the individual manner in which complaints are currently approached by the Committee places a natural limit on the recognition of structural problems, which end up being reduced to and coached in the narrower terms of specific individual complaints.

Although the Optional Protocol providing for this system of individual complaints does not explicitly foresee the possibility of a pilot procedure, it does not seem to preclude it either, as long as the Committee ultimately adopts views on communications "submitted by or on behalf of individuals or groups of individuals, under the jurisdiction of a State

43 The list of pending cases is available at:
https://www.ohchr.org/EN/HRBodies/CESCR/Pages/PendingCases.aspx.

${ }^{44}$ Markus Fyrnys, "Expanding Competences by Judicial Lawmaking: The Pilot Judgment Procedure of the European Court of Human Rights," German Law Journal 12, no. 5 (2011): 1232-33; Luzius Wildhaber, "Pilot Judgments in Cases of Structural or Systemic Problems on the National Level," in The European Court of Human Rights Overwhelmed by Applications: Problems and Possible Solutions, ed. Ulrike Deutsch and Rüdiger Wolfrum, Beiträge zum ausländischen öffentlichen Recht und Völkerrecht 205 (Berlin: Springer, 2009), 71. 
Party, claiming to be victims of a violation of any of the economic, social and cultural rights set forth in the Covenant by that State Party." 45

This would allow the CESCR to focus more effectively on structural and systemic failures breaching human rights, notably with regard to the right to adequate housing in Spain and the domestic legal framework governing evictions. Dealing with a few dozen of very similar cases as a whole would send a very powerful message to Spain and the international community as to the extent of these human rights violations and their collective dimension, going beyond the force of CESCR concluding observations in the framework of the periodic reporting procedure while remaining at the same time within the bounds of the individual complaint mechanism.

Secondly, the Committee made a strong statement in López Albán regarding the role of growing inequality and housing market speculation in the housing affordability crisis, linking this to stigmatisation and systemic discrimination on the basis of socioeconomic disadvantage. This is of particular relevance, as it links to broader trends in international human rights and antidiscrimination law recognising the centrality of socioeconomic disadvantage and of intersectional discrimination within many human rights violations. The draft guidelines for the implementation of the right to adequate housing recently elaborated by the UN Special Rapporteur on adequate housing as a component of the right to an adequate standard of living, and on the right to non-discrimination in this context, Ms. Leilani Farha, notably emphasise this dimension. ${ }^{46}$

In this sense, one of the key issues that has not explicitly emerged in the cases decided until now is the equality and nondiscrimination dimension of most of these violations, including from a socioeconomic perspective. ${ }^{47}$ It can be recalled that in 2018, in its Concluding observations on the sixth periodic report of Spain, the CESCR urged Spain to:

\footnotetext{
${ }^{45}$ United Nations, Optional Protocol to the International Covenant on Economic, Social and Cultural Rights, art. 2.

${ }^{46}$ In their draft version of November 2019, these guidelines state that : "Refugees, migrants, persons with disabilities, children and youth, indigenous peoples, women, LGBT and racial and ethnic minorities are disproportionately represented among those living in homelessness, informality and inadequate housing, and often relegated to the most marginal and unsafe areas to live. Discrimination against these groups is compounded by intersectional discrimination linked to their housing status: being homeless, living in informality or in neighbourhoods with a high percentage of inadequate or dilapidated housing. Discriminatory exclusion from housing greatly exacerbates and reinforces socio-economic inequality for these groups."

See further at: https://www.ohchr.org/EN/Issues/Housing/Pages/GuidelinesImplementation.aspx.

${ }^{47}$ See, on the issue of socioeconomic disadvantage in the context of housing, Juan Carlos Benito Sánchez,

"Towering Grenfell: Reflections around Socioeconomic Disadvantage in Antidiscrimination Law," Queen Mary Human Rights Law Review 5, no. 2 (2019). See also more generally Diane Roman, "La discrimination fondée sur la condition sociale, une catégorie manquante du droit français," Recueil Dalloz, no. 28 (2013): 1911-1918; Ioannis Rodopoulos, "L'absence de la précarité sociale parmi les motifs de discrimination reconnus par le droit français : un frein normatif à l'effectivité de la lutte contre les discriminations ?, $L a$ Revue des droits de l'homme 9 (2016); Margaret Thornton, "Social Status: The Last Bastion of Discrimination," Anti-Discrimination Law Review 2018, no. 1 (2018): 5-26.
} 
Adopt a comprehensive law on non-discrimination that guarantees adequate protection and explicitly includes all the prohibited grounds for discrimination referred to in article 2 (2) of the Covenant; defines multiple discrimination, as well as direct and indirect discrimination, in accordance with the State party's obligations under the Covenant; prohibits discrimination in both the public and the private spheres; and incorporates provisions under which redress can be obtained in cases of discrimination, including by judicial and administrative means. It also recommends that the State party redouble its efforts to prevent and combat persistent discrimination, in particular against Gitanos and Roma, persons with disabilities, migrants, refugees and asylum seekers, including by conducting awareness-raising campaigns, in order to guarantee full exercise of the rights recognized in the Covenant by such persons. ${ }^{48}$

In future decisions on individual complaints, the Committee should more clearly acknowledge how the existing framework governing evictions in Spain disproportionately impacts on certain vulnerable groups, and may create indirect discrimination on the basis of racial or ethnic origin, gender, disability, age, migrant status, and economic and social situation. In many cases, most of these factors interact with each other to create intersectional discrimination, notion which should also bear some weight in future CESCR decisions. ${ }^{49}$ Although discrimination issues have perhaps not been yet sufficiently raised in individual complaints, possibly owing to the weak antidiscrimination law framework existing in Spain and to a domestic judicial praxis where arguments based on antidiscrimination law have a narrow chance of succeeding, this is a crucial dimension that needs to be highlighted from a human rights standpoint.

Once again, taking a step from a more general statement in concluding observations to a more localised and contextual finding in the framework of an individual complaint would make these underpinning issues more visible and enhance the relevance of the equality and nondiscrimination dimension of economic, social, and cultural rights. It can be recalled in this sense that the CESCR noted in its General Comment No. 20 that "individuals and groups of individuals must not be arbitrarily treated on account of belonging to a certain economic or social group or strata within society. A person's social and economic situation when living in poverty or being homeless may result in pervasive discrimination, stigmatization and negative stereotyping." 50 While the Committee has hinted towards this aspect in López Albán, a more robust approach would be welcome, especially in light of such structural threats to the right to adequate housing in Spain.

\footnotetext{
${ }^{48}$ United Nations, Committee on Economic, Social and Cultural Rights, Concluding observations on the sixth periodic report of Spain, E/C.12/ESP/CO/6 (25 April 2018), para. 18.

${ }^{49}$ See, on the issue of discrimination in the field of housing, Ringelheim, Julie, and Nicolas Bernard. Discrimination in Housing. Luxembourg: European Network of Legal Experts in the Non-Discrimination Field, 2013. https://www.equalitylaw.eu/downloads/1337-discrimination-in-housing-en.

${ }^{50}$ United Nations, Committee on Economic, Social and Cultural Rights, General Comment no. 20: Nondiscrimination in economic, social and cultural rights (art. 2, para. 2, of the International Covenant on Economic, Social and Cultural Rights), E/C.12/GC/20 (2 July 2009), para. 35.
} 


\section{Conclusion.}

The CESCR decision in López Albán follows the doctrinal line established in the Ben Djazia and Bellili case and in previous CESCR General Comments. It confirms that the protection afforded by the ICESCR against forced evictions also applies to persons occupying dwellings without a legal title, be they bona fide or out-of-necessity occupants. At the same time, it provides a number of new and important legal insights and clarifications, such as the difference between emergency shelter and adequate housing, the fact that the state cannot allow for the immediate eviction of a person regardless of the circumstances, or examples of the factors that courts ought to take into account when conducting a proportionality assessment. This expansive interpretation of the safeguards surrounding the right to housing stands in stark contrast with the increasingly more restrictive case law of the European Court of Human Rights. Two possible legal avenues for the CESCR to explore in future decisions could be resorting to a "pilot" procedure that reflects the structural and systemic character of the violations of the right to housing taking place in Spain, on the one hand, and acknowledging the discriminatory impact of the domestic legal framework governing evictions, on the other hand.

\section{Bibliography.}

Atrey, Shreya. "The Intersectional Case of Poverty in Discrimination Law." Human Rights Law Review 18, no. 3 (2018): 411-440.

Benito Sánchez, Juan Carlos. "Los pronunciamientos del Comité DESC sobre derecho a la vivienda relativos a España. Respuestas jurisprudenciales y legislativas." Lex Social, Revista de Derechos Sociales 9, no. 2 (2019): 579-603.

—. "Towering Grenfell: Reflections around Socioeconomic Disadvantage in Antidiscrimination Law." Queen Mary Human Rights Law Review 5, no. 2 (2019).

Bernard, Nicolas. "La protection conventionnelle du domicile tombe-t-elle lorsqu'on l'invoque contre un particulier? La longue quête de l'horizontalisation des droits de l'homme (obs. sous Cour eur. dr. h., décision F.J.M. c. Royaume-Uni, 6 novembre 2018)." Revue trimestrielle des droits de l'homme 2019, no. 120 (2019): 891-923.

Fick, Sarah, and Michel Vols. "Best Protection Against Eviction? A Comparative Analysis of Protection Against Evictions in the European Convention on Human Rights and the South African Constitution." European Journal of Comparative Law and Governance 3 (2016): 40-69.

Fyrnys, Markus. "Expanding Competences by Judicial Lawmaking: The Pilot Judgment Procedure of the European Court of Human Rights." German Law Journal 12, no. 5 (2011): 1231-60.

Goldblatt, Beth. "Intersectionality in International Anti-Discrimination Law: Addressing Poverty in Its Complexity.” Australian Journal of Human Rights 21, no. 1 (2015): $47-70$. 
Hohmann, Jessie. The Right to Housing: Law, Concepts, Possibilities. Oxford: Hart Publishing, 2013.

Kenna, Padraic. "Introduction." In Loss of Homes and Evictions across Europe: A Comparative Legal and Policy Examination, edited by Padraic Kenna, Sergio Nasarre-Aznar, Peter Sparkes, and Christoph U. Schmid, 1-65. Elgar Land and Housing Law and Policy. Cheltenham: Edward Elgar, 2018.

Macho Carro, Alberto. "La naturaleza jurídica del Comité de derechos económicos, sociales y culturales de Naciones Unidas y de sus pronunciamientos. Especial atención al caso español." Papeles El tiempo de los derechos. HURIAGE - Red Tiempo de los derechos, 2019.

Madden, David, and Peter Marcuse. In Defense of Housing: The Politics of Crisis. London: Verso, 2016.

Marushiakova, Elena, and Vesselin Popov. "Who Are Roma?" In Roma Culture: Myths and Realities, edited by Elena Marushiakova and Vesselin Popov. Roma Series, Vol. 3. Munich: Lincom Academic Publisher, 2016.

Ringelheim, Julie, and Nicolas Bernard. Discrimination in Housing. Luxembourg: European Network of Legal Experts in the Non-Discrimination Field, 2013.

Rodopoulos, Ioannis. "L'absence de la précarité sociale parmi les motifs de discrimination reconnus par le droit français : un frein normatif à l'effectivité de la lutte contre les discriminations ?" La Revue des droits de l'homme 9 (2016).

Romainville, Céline, and Nicolas Bernard. "Le droit à l'habitat des gens du voyage." In Le droit et la diversité culturelle, edited by Julie Ringelheim, 745-818. Collection du Centre des droits de l'homme de l'Université catholique de Louvain. Brussels: Bruylant, 2011.

Roman, Diane. "La discrimination fondée sur la condition sociale, une catégorie manquante du droit français." Recueil Dalloz, no. 28 (2013): 1911-1918.

Ryan-Collins, Josh, Toby Lloyd, Laurie Macfarlane, and John Muellbauer. Rethinking the Economics of Land and Housing. London: Zed, 2017.

Thornton, Margaret. "Social Status: The Last Bastion of Discrimination." AntiDiscrimination Law Review 2018, no. 1 (2018): 5-26.

Wildhaber, Luzius. "Pilot Judgments in Cases of Structural or Systemic Problems on the National Level." In The European Court of Human Rights Overwhelmed by Applications: Problems and Possible Solutions, edited by Ulrike Deutsch and Rüdiger Wolfrum, 69-75. Beiträge zum ausländischen öffentlichen Recht und Völkerrecht 205. Berlin: Springer, 2009. 